\title{
Developing Learning Tools Guided Discovery Models Assisted PhET Simulations for Training Critical Thinking Skills High School Students
}

\author{
U H Thohari ${ }^{1}$; Madlazim; Y S Rahayu ${ }^{2}$ \\ ${ }^{1}$ Student Postgraduate in Science Education, Surabaya State University, Jawa Timur, Indonesia \\ ${ }^{2}$ Postgraduate Lecturer in Science Education, Surabaya State University, Jawa Timur, Indonesia
}

http://dx.doi.org/10.18415/ijmmu.v6i4.1008

\begin{abstract}
This research is aimed to develop learning device of Guided Discovery model with PhET simulation to trill students critical thinking skill. This research uses 4D development model and tested on 15 students of class XII IPA with test design using one group pretest-posttest design. Learning tools developed include: (a) syllabus (b) RPP, (c) student books, (d) LKS, and (e) tests students' critical thinking skills. Research data obtained through validation method, observation, test, and questionnaire. The results are analyzed descriptively quantitative and qualitative. The students' critical thinking ability is analyzed by n-gain. The result of the research shows that (a) learning device developed categorized is very valid, (b) learning activity is done very well, (c) critical thinking ability of students have moderate improvement, and (d) students respond very positively to learning which has been implemented. Based on the results of the analysis and discussion, it was concluded that the learning device of Guided Discovery with PhET simulation model developed is feasible to be used for trained critical thinking skills of high school students.
\end{abstract}

Keywords: Discovery Models; PhET Simulations; High School Students

\section{Introduction}

In the 21st century, education is a reference for the progress of a country. Quality human resources are created because the state has a good education system. The people of Indonesia who are prosperous and happy are realized through national education, with an honorable and equal position with other nations in the global world, through the formation of a society consisting of qualified human resources, namely individuals who are independent, willing and capable of realizing dreams the nation (BSNP, 2010). The quality and readiness of students for changing times is improved through education.

To give birth to a quality educated generation, education in Indonesia can be improved by innovating a lot. One breakthrough that can be done is by utilizing guided discovery learning models. The guided discovery model is a learning activity that involves all the abilities of students to find and find 
something mathematically, critically, logically and analytically so they can formulate their own findings. The model is built on the basis of constructivist theory which has the idea that students must build knowledge in themselves. In other words the ability of students is obtained based on the learning activities carried out in the classroom.

Seeing the demand for such education, the Indonesian government has sought to perfect the education system both through structuring software and hardware (Mulyasa, 2013: 4). One example is the existence of hardware and software and supporting learning. The form of hardware in this case is a learning device. Learning devices are tools to help and facilitate learning activities to achieve predetermined goals (Ibrahim, 2002). Learning tools needed in managing the learning process can be in the form of syllabi, learning implementation plans, student activity sheets, evaluation instruments or learning outcomes tests, and textbooks.

Meanwhile, information technology that is growing rapidly every year also affects the software development in the world of education. One software that can be used in learning is the PhET application in physics lessons. PhET (Physics Education Technology) is a site that provides physics and chemical learning simulations downloaded for the purposes of classroom teaching or can be used for individual learning purposes. PhET interactive simulations are animated images, interactive and made like games where students can learn by exploring.

One way to improve the quality of students in Indonesia is to train critical thinking skills. The ability to think critically is a very essential ability, and functions effectively in all aspects of life (Deti Ahmatika, 2016: 394). According to Ibrahim (2007), that to bring towards learning that can develop the ability to think critically and creatively must depart from learning that makes students active. This means that the optimal learning process requires critical thinking from the learner.

In a learning process, students' thinking skills can be developed by enriching meaningful experiences through problem solving problems. Experience or learning that provides opportunities for students to acquire skills in problem solving, so that their thinking skills can be developed. Thus, developing thinking skills, both critical thinking and creative thinking is an important thing to do and needs to be trained in students starting from the basic education level to secondary education (Euis Istianah, 2013).

Departing from the explanation above, this study seeks to develop an innovation in the learning process. This study develops a learning device (hardware) with a guided discovery model assisted by PhET simulation (software). This combination of hardware and software aims to train students' critical thinking skills.

\section{Literature Review}

\section{Learning Tools}

According to Suhadi (2007: 2) learning devices are a number of materials, tools, media, instructions, and guidelines that can be used in learning activities. Learning tools needed in managing the teaching and learning process can be in the form of: student books, syllabus, Learning Implementation Plans (RPP), Student Activity Sheets (LKS), Learning Outcomes Evaluation Instruments (THB), and learning media (Ibrahim in Trianto, 2010 : 96). The learning devices developed are as follows: 


\subsection{Table type of learning device}

\begin{tabular}{lll}
\hline No & Term & Information \\
\hline 1 & Syllabus & $\begin{array}{l}\text { Syllabus, is a learning plan for a particular subject and / or group or theme that } \\
\text { includes Competency Standards, Basic Competencies, subject matter / } \\
\text { learning, learning activities, indicators, achievement of competencies for } \\
\text { assessment, time allocation, and learning resources (Trianto, 2010: 96). }\end{array}$ \\
\hline 2 & Rpp & $\begin{array}{l}\text { The description of the syllabus to direct student learning activities in an effort } \\
\text { to achieve basic competencies (Rusman, 2014: 5). }\end{array}$ \\
\hline 3 & Student book & $\begin{array}{l}\text { guidebooks for students in learning activities that include subject matter, } \\
\text { inquiry activities based on concepts, science activities, information, and } \\
\text { examples of the application of science in everyday life (Trianto, 2012: 112). }\end{array}$ \\
\hline 4 & LKS & $\begin{array}{l}\text { are sheets that contain instructions or steps to complete a task that must be } \\
\text { done by students (Abdul Majid, 2008: 176). }\end{array}$ \\
\hline 5 & Assessment & $\begin{array}{l}\text { assessment is a series of activities to obtain information or data concerning the } \\
\text { process and learning outcomes of students (Kemendikbud, 2016: 10) }\end{array}$ \\
\hline
\end{tabular}

\section{Guided Discovery Model with PhET Simulation}

Rustaman (2011: 2.17) revealed that the development of learning models according to constructivist views must pay attention to and consider the students' initial knowledge that might be obtained outside of school and in learning must involve students in a real activity. Therefore, the learning model is closely related to the learning style and teaching style, both of which are abbreviated to SOLAT (Style of Learning and Teaching) (Nanang Hanafiah and Cucu Suhana, 2010: 41) . One learning model that can be used is guided discovery.

According to Newhall J (in Eggen P, 2012, h. 197) guided discovery learning model is a teaching approach where the teacher gives students specific topic examples and guides students to understand the topic. This model is effective in encouraging student involvement and motivation while helping them gain an in-depth understanding of clear topics. Furthermore, Guided Discovery Learning has four advantages, namely: intellectual potential, intrinstic motivation, heuristic discovery and memory (Carin in Mutoharoh, 2011).

In practice, guided discovery can be combined with various educational methods and innovations. One of them is the use of PhET in physics learning. According to Kagan et al. (2008), PhET are the simulations are animated, interactive, and game-like environments where students learn through exploration. PhET simulation emphasizes the relationship between real-life phenomena and underlying science, supports interactive and constructivist approaches, provides feedback, and provides a creative workplace (Finkelstein, 2006). Thus, guided discovery can be practiced with simulations because it emphasizes the process of constructivist learning.

\section{Critical Thinking}

Thinking is a natural process, but left to itself, it is often biased, distorted, partial, uninformed, and potentially prejudiced; excellence in thought must be cultivated (Scriven and Paul, 2007). Thinking is an activeness of the human person which results in a discovery that is directed towards a goal. Thinking is also a mental activity to build and acquire knowledge. Humans can think with each other's logic, but not 
everyone is capable of high-level thinking. One of the thinking skills included in high-level thinking skills is the ability to think critically.

According to fisher (2009) Critical thinking is a model of thinking about things, substance, or any problem where the thinker increases the quality of his thinking by handling skillfully the structures inherent in thinking and applying intellectual standards. The same thing was stated also by Scriven \& Paul (2007, p. 1) that Critical thinking can define as "the intellectually disciplined process of active and skillfully conceptualizing, applying, analyzing, synthesizing, and / or evaluating information gathered from, or generated by, observation, experience, reflection, reasoning, or communication, as a guide to belief and action."

\section{Method}

This research was carried out at Wup Songo Mantup High School, Lamongan district. The population used is all students of class XII MIPA by taking a sample of 15 students. This research is research and development which refers to the 4-D model according to Thiagarajan. This model consists of 4 development stages, namely: define, design, develope, and disseminate. The test was conducted using the One Group Pretest-Posttest Design method. The results are descriptively quantitative and qualitative. The students' critical thinking abilities are analyzed by n-gain.

\section{Result and Discussion}

\section{Product Validity}

Products developed, first validated by experts and practitioners. Data from the validation results were analyzed using qualitative descriptive analysis techniques. Percentage of appraisal match of two validators of physics products based on the inter observer agreement obtained from statistical analysis of percentage of agreement (R) (Borich, 1994):

$$
R=\left[1-\left\{\frac{A-B}{A+B}\right\}\right] \times 100 \%
$$

Description: $\mathrm{R}=$ percentage of agreement, $\mathrm{A}=$ highest score of 2 assessors, $\mathrm{B}=$ lowest score of 2 assessors

The results of the validation test obtained are as follows: first, the syllabus validation test. In general, the syllabus developed has a valid category with a final average score of 3.43 . The percentage of suitability of the syllabus developed was $86 \%$. Second, RPP validation test. In general, the developed RPP has a valid category with a final average score of 3.47. The percentage of appropriateness of the assessment of the developed lesson plan is $87 \%$. Third, the validation test of textbooks. In general the developed textbook has a valid category with a final average score of 3.41. The percentage of suitability of the assessment of the textbook developed is $85 \%$. Fourth, validation test of LKPD. In general, the developed LKPD has a valid category with a final average score of 3.41. The percentage of suitability of the assessment of the developed LKPD is $85 \%$. Fifth, the validation test of the Critical Thinking Ability Test. In general, the ability test developed has a valid category with a final average score of 3.30. The percentage of appraisal of the ability test developed is $83 \%$. 


\section{Critical Thinking Test}

Products developed, then tested on several research objects. Data from the pretest and posttest skills of students were analyzed by n-gain. $\mathrm{N}$-gain shows improvement in students' critical thinking skills before and after treatment. The formula used is

$$
\begin{aligned}
& \langle g\rangle=\frac{\text { Spost }- \text { Spre }}{\text { Smax-Spre }} \\
& \text { With: } \\
& \langle g\rangle: \text { n-gain score } \\
& \text { Spost : posttest score } \\
& \text { Spre : pretest score } \\
& \text { Smax : maximum score }
\end{aligned}
$$

The results of the n-gain calculation are then converted by Hake (1999) model to the following criteria:

Table 4.1 Normalized Gain Criteria

\begin{tabular}{ll}
\hline N-Gain score & Normalized Gain Criteria \\
\hline $0.70 \leq N$-Gain & High \\
\hline $0.30 \leq N$-Gain $<0.70$ & Is Being \\
\hline$N$-Gain $<0.30$ & Low \\
\hline
\end{tabular}

Of the 15 students who were the object of the research there were 12 students with a high category $\mathrm{N}$-gain value and 3 students with an $\mathrm{N}$-gain value in the medium category. While for the average $\mathrm{N}$-gain score of 0.74 , which means high category means that students' critical thinking skills have significant differences between before and after learning. Overall there is a positive impact on students from guided discovery learning models given to critical thinking skills.

\section{Learning Activity}

Learning activities in the classroom are assessed from the results of observations by two observers. Data is presented in the form of descriptive quantitative-qualitative. Learning consists of three activities, namely introduction, core activities, and closed activities. The three main activities have covered the syntax of guided discovery models that have been developed specifically to train students' critical thinking skills. Guided discovery learning is closely related to experiment-based activities that are heavily involved with experimental data or observations to strengthen students' thinking skills. Learning activities carried out were integrated with the PhET laboratory as a means of conducting experiments.

Learning activities using learning tools developed make students feel happy and not afraid of the teacher, this is due to the approach in the form of guidance during the learning process takes place. This guidance will be further reduced every meeting if students are able to be independent. Guidance given by the teacher is in the form of analogies and questions, this is given in training students' critical thinking skills.

Based on the results of the observer's analysis, the implementation of classroom learning was carried out very well. Accuracy of learning seen from the observation sheet analyzed using the inter observer agreement method obtained from statistical analysis of percentage of agreement (R) (Borich, 
1994). The implementation of learning has a good category with an average score of observations of 3.45 and a percentage of appraisal match of 2 observers at $83 \%$.

In general, teachers and students follow high-enthusiasm learning activities. The results of observations on the class atmosphere in class XII MIPA obtained an average score of 3.45. This shows that students are very interested in the learning delivered by the teacher. The teacher is able to melt the atmosphere and revive the atmosphere in the classroom, so learning is fun. physics learning devices model guided discovery assisted PhET to train critical thinking skills result in students being more active in learning activities. Learning using virtual laboratories has been shown to increase student activity (Yusuf \& Subaer, 2013; Yusuf, et al., 2015).

\section{Critical Thinking in Classroom}

The premise of that critical thinking is that critical thinking is a learned skill that must be developed, practiced, and continually integrated into active learning (Lisa Gueldenzoph Snyder \& Mark J. Snyder, 2008). Active learning can make the course more enjoyable for both teachers and students, and, most importantly, it can be students to think critically (Robert Duron, Barbara Limbach \& Wendy Waugh, 2006). Teacher as a frontier in education should be able to carry out the mandate in training critical thinking for students (Nur Miftahul Fuad, etc. (2017).

In the learning process, critical thinking skills are important because they enable students to deal effectively with social, scientific, and practical problems (Shakirova, 2007, p. 42). Critical thinking is a skill needed to foster students' thinking skills (Hashemi, 2011). As part of the process of training and preparing themselves before entering community life, students should be trained to think critically. when students have critical thinking skills, they will be able to solve problems effectively (Lisa Gueldenzoph Snyder \& Mark J. Snyder 2008).

In training critical thinking skills to students, researchers are guided by the opinion of Clement (1979) who suggested that "we should be teaching students how to think". Students must be trained on how to think rather than teach what they have to think about. In accordance with the clement concept, the way / or step in training critical thinking skills is very important. Practicing critical thinking skills in the learning process certainly has an impact on the future of students (Linda M. Murawski, 2014).

\section{Conclusion}

Based on the results of the study, it was concluded that the learning device developed had met the criteria of valid, practical, and effective so that it was appropriate to be used to train students' critical thinking skills. 


\section{References}

Ahmatika,Deti.(2016).Peningkatan Kemampuan Berpikir Kritis Siswa Dengan Pendekatan Inquiry/Discovery. Jurnal Euclid, vol.3, No.1, p.394-403.

BSNP. (2010). Paradigma Pendidikan Nasional Abad XXI versi 01 Tahun 2010.

Clement, J. (1979). Introduction to Research In Cognitive Process Instruction. In Lochhead, J. and Clement, J. (Eds.), Cognitive Process Instruction. Hillsdale, NJ: Lawrence Erlbaum Associates.

Duron, Robert., Limbach, Barbara., \& Waugh, Wendy. 2006. Critical Thinking Framework for Any Discipline. International Journal of Teaching and Learning in Higher Education 2006, Volume 17, Number 2, 160-166.

Fuad, Nur Miftahul., Zubaidah, Siti., Mahanal, Susriyati., And Suarsini, Endang. (2017). Improving Junior High Schools' Critical Thinking Skills Based On Test Three Different Models of Learning. International Journal Of Instruction. January 2017 • Vol.10, No.1, Pp. 101-116.

Hashemi, Seyed Ahmad. 2011. The Use of Critical Thinking in Social Science Textbooks of High School: A Field Study of Fars Province in Iran. International Journal of Instruction. January 2011 Vol.4, No.1. 63-78.

Ibrahim (2007). Pengembangan Kemampuan Berpikir Kritis dan Kreatif Siswa SMP dalam Matematika melalui Pendekatan Advokasi dengan Penyajian Masalah Open-Ended. Tesis Sekolah Pasca Sarjana UPI. Bandung: Tidak dipublikasikan.

Istianah, Euis. (2013). Meningkatkan Kemampuan Berpikir Kritis Dan Kreatif Matematik Dengan Pendekatan Model Eliciting Activities (Meas) Pada Siswa. (Infinity) Jurnal Ilmiah Program Studi Matematika STKIP Siliwangi Bandung, Vol 2, No.1, Februari 2013.

Murawski Linda M (2014) Critical Thinking in The Classroom And Beyond Journal Of Learning In Higher Education, Spring 2014 (Volume 10 Issue 1)25-30.

Nanang Hanafiah dan Cucu Suhana, Konsep Strategi Pembelajaran, (Bandung: PT. Refika Aditama, 2010), hal. 41.

Scriven, M., \& Paul, R. (2007). The Critical Thinking Community. Dari Http://Www.Criticalthinking.Org/Aboutct/Definin Gct.Shtml.

Shakirova D. M. (2007) Technology for The Shaping Of College Students' And Upper-Grade Students' Critical Thinking. Russian Education \& Society, 49(9), 42-52.

Snyder, Lisa Gueldenzoph \& Snyder, Mark J. (2008) The Delta Pi Epsilon Journal Volume L, No. 2, Spring/Summer, 90-99. 


\section{Copyrights}

Copyright for this article is retained by the author(s), with first publication rights granted to the journal. This is an open-access article distributed under the terms and conditions of the Creative Commons Attribution license (http://creativecommons.org/licenses/by/4.0/). 